\title{
Serum zinc and copper levels in children with febrile convulsion
}

\author{
Mohammad Shokrzadeh', Ali Abbaskhaniyan², Mohammadreza Rafati ${ }^{3 *}$, Mahdi Mashhadiakabr ${ }^{4}$, Ali Arab $^{2}$ \\ ${ }^{1}$ Pharmaceutical Sciences Research Center, Department of Toxicology and Pharmacology, Faculty of Pharmacy, Mazandaran University of Medical \\ Science, Sari, Iran \\ ${ }^{2}$ Department of Pediatrics, Faculty of Medicine, Mazandaran University of Medical Science, Sari, Iran \\ ${ }^{3}$ Pharmaceutical Sciences Research Center, Department of Clinical Pharmacy, Faculty of Pharmacy, Mazandaran University of Medical Science, Sari, \\ Iran \\ ${ }^{4}$ Mazandaran University of Medical Science, Sari, Iran
}

Received: Jul 30, 2016, Revised: Aug 22, 2016, Accepted: Sep 10, 2016

\begin{abstract}
Febrile convulsions (FC) are the most common neurologic disorder in children 6-60 months of age. Zinc (Zn) and copper (Cu) play role as cofactors in more than 300 enzymatic activities significantly. The aim of this study was to evaluate the relationship serum levels of $\mathrm{Zn}$ and $\mathrm{Cu}$ with seizure occurrence in febrile children. In this case-control study, 270 children with 6 month to 6 years were evaluated. The patients were enrolled in three groups: a) children with febrile convulsion, b) febrile children without convulsion and c) healthy ones. After recording of all patients' characteristics, $5 \mathrm{~mL}$ blood was taken from peripheral vessels at the first 12 hours of hospitalization. Absorption of all samples was read by BRAIC (Rayleigh instrument) company, WFX-130 model with calibration diagram, considering samples dilution levels. The mean of serum Zn levels in children with FC were significantly lower than other two groups. Mean serum Cu levels in children with FC and non-FC patients were significantly higher than healthy children. No meaningful differences were observed in serum levels of $\mathrm{Zn}$ and $\mathrm{Cu}$ among the girl or boy cases. This study showed significant lower serum zinc level in children with febrile seizure and meaningful higher serum copper level than control group cases. There was no significant difference in level of serum zinc and copper in term of sex.
\end{abstract}

Keywords: Children, seizure, fever, zinc, copper

Pharm Biomed Res 2016; 2(3): 19-24

DOI: 10.18869/acadpub.pbr.2.3.19

\section{Introduction}

Febrile seizures or febrile convulsions (FC) are the most common neurologic disorder of infants and children 6 through 60 months of age. They are age-dependent phenomenon, occurring in 2 to 5 percent of children younger than six years of age and are usually associated with fever (a temperature greater than $38^{\circ} \mathrm{C}$ ) but without evidence of intracranial infection or defined cause (1). If convulsion lasts more than 5 minutes, complications such as mental disability, hemiplegia and death will threaten children. Despite the fact that the exact mechanisms of fever and seizure genesis are not known yet, many etiologic factors contribute in creating it and the occurrence of fever alone does not result in convulsion in this group. In other hands, fever in these children is necessary but not enough. It has been proved that genetics plays a meaningful role in seizure type as a triggering factor (2).
Besides genetic factor, family background, immunologic disorders, iron deficiency, neural intermediaries' changes and trace elements effective on these intermediaries have been recognized to involve in this disease except of metal elements (3-5). Zinc ( $\mathrm{Zn}$ ) and copper $(\mathrm{Cu})$ (human body basic cations) play role as cofactors in more than 300 enzymatic activities significantly (6). $\mathrm{Zn}$ ion is a necessary element with high importance for brain natural development (7) especially gamma-aminobutyric acid (GABA) pathway that reduction of its activity can create convulsion (8). Hypozincemia activates the NMDA receptor, one of the glutamate families of receptors, which may play an important role in the induction of epileptic electrical discharges (8).

Fever is a clinical signal that is characterized by rising body temperature more than normal level. 
Hypothalamus controls the central body temperature in normal conditions, and set within the normal range (36.5-37.5 ${ }^{\circ} \mathrm{C}$ ). An exogenous pyrogen (external feverinducing substance such as gram-negative bacteria lipopolysaccharide) or endogenous ones (such as interleukin-1) caused fever by acting directly on the hypothalamic thermoregulatory center and then rise body temperature by releasing epinephrine, vessels contraction (particularly peripheral vessels), finally reach a new regulation point and fever occurs $(9,10)$.

Considering of febrile seizures' incidence and probably their complications, high hospitalization costs, and ability to fear parents, identification of causes for their prevention are very essential. This study was evaluated the relationship serum levels of $\mathrm{Zn}$ and $\mathrm{Cu}$ with seizure occurrence and fever intensity in febrile children.

\section{Materials and methods}

In this case-control study, serum $\mathrm{Zn}$ and $\mathrm{Cu}$ levels of 270 children with febrile seizure, referring to a teaching hospital (Bu-Ali Sina, Sari, Iran), during 2 years evaluated. The study was approved by the Ethical and Research Committee of Mazandaran University of Medical Sciences (No: 88-142). Patients were 6 month to 6 years age bracket (samples number has been calculated based on previous studies sample volume \& sample volume formula) (3-5). After explaining to parents and getting their consent, cases entered to study and examined by a pediatric neurology specialist to place in one of 3 groups: a) children with febrile convulsion, b) febrile children without convulsion and c) healthy ones (without fever and convulsion).

The exclusion criteria for patients in this study were including age younger than 6 months and older than 6 years, mental or cerebral retardation or sings of genetic syndrome, complex convulsion (atypical), chronic disease (heart, liver, kidney), malnutrition and situations that lead to decrease study metals levels in serum including hemolysis, dehydration, vomiting, dysentery and pneumonia.

After physical exams and measuring the body temperature to confirm the fever of case and controls, 5 $\mathrm{mL}$ blood was taken from peripheral vessels at the first 12 hours of hospitalization. All patients' characteristics were recorded and under sterile conditions, samples transferred to hospital laboratory for centrifuge and isolation of serum from globule and then serum was kept at $-20{ }^{\circ} \mathrm{C}$. At the end of sampling, all samples were defreeze and diluted using $10 \%$ triton in 0.1 normal nitric acid solutions (Merck, Germany) to 1:10 level. Four standard concentrations were made for $\mathrm{Zn}$ and $\mathrm{Cu}$.

Standard powders of $\mathrm{Zn}$ and $\mathrm{Cu}$ prepared from Merck (Germany) and atomic absorption level of standard solutions was measured by using atomic absorption method and then concentration-absorption calibration diagram was drawn. Absorption of all samples was read by the same instrument with calibration diagram, considering samples dilution levels with atomic absorption spectrophotometer made by Beijing Rayleigh Analytical Instrument Corporation (BRAIC) company, WFX-130 model (China).

\section{Statistical analysis}

Data were analyzed by SPSS16 software (Chicago, USA), independent samples t-test and ANOVA were used to compare serum levels between study groups and Pvalue $\leq 0.05$ was considered statistically significant.

\section{Results}

Patients demographic characteristics presented in Table 1. It was insignificantly differences between three groups in age, weight and gender.

No meaningful differences were observed in serum levels of $\mathrm{Zn}$ and $\mathrm{Cu}$ among the girl or boy cases (Table 2 and 3 ). The mean of serum $\mathrm{Zn}$ levels in children with $\mathrm{FC}(0.43 \pm$ $0.38 \mathrm{mg} / \mathrm{l}$ ) were significantly lower than other two groups (Table 4). Also, serum Zn levels in convulsion free febrile children $(0.66 \pm 0.37 \mathrm{mg} / \mathrm{l})$ had meaningful difference with healthy group patients $(0.97 \pm 0.15 \mathrm{mg} / \mathrm{l})$.

Serum $\mathrm{Cu}$ concentrations in three study groups were reported in table 5. Mean serum $\mathrm{Cu}$ levels in children with $\mathrm{FC}$ and non-FC patients $(1.16 \pm 0.38$ and $1.53 \pm$ $0.76 \mathrm{mg} / \mathrm{l}$, respectively) were significantly higher than healthy children $0.53 \pm 0.24 \mathrm{mg} / \mathrm{l}(\mathrm{p}$ value $<0.05$ ).

\section{Discussion}

The results of the present study demonstrated children with fever convulsion had significantly lower serum $\mathrm{Zn}$ levels than two other groups (febrile children without 
Tablel 1 Demographic characteristics of the study patients

\begin{tabular}{ccccc}
\hline & $\begin{array}{c}\text { FC group } \\
\text { Mean } \pm \text { SD }\end{array}$ & $\begin{array}{c}\text { Non-FC group } \\
\text { Mean } \pm \text { SD }\end{array}$ & $\begin{array}{c}\text { Healthy group } \\
\text { Mean } \pm \text { SD }\end{array}$ \\
\hline Gender & Girls & 61 & 43 & 52 \\
\cline { 2 - 5 } & Boys & 31 & 50 & 41 \\
\hline Age (month) & $26.15 \pm 16.60$ & $29.22 \pm 20.25$ & $26.57 \pm 14.03$ \\
\hline Weight (kg) & $11.98 \pm 3.20$ & $12.52 \pm 3.78$ & $13.64 \pm 2.31$ \\
\hline FC: febrile convulsion & &
\end{tabular}

FC: febrile convulsion

Table 2 Relation of serum $\mathrm{Zn}$ concentration by gender

\begin{tabular}{cccc}
\hline & \multicolumn{3}{c}{ Zn level $(\mathbf{m g} / \mathbf{L})$} \\
\hline & $\begin{array}{c}\text { FC group } \\
\text { Mean } \pm \text { SD }\end{array}$ & $\begin{array}{c}\text { Non-FC group } \\
\text { Mean } \pm \text { SD }\end{array}$ & $\begin{array}{c}\text { Healthy group } \\
\text { Mean } \pm \text { SD }\end{array}$ \\
\hline Boys & $0.58 \pm 0.27$ & $0.614 \pm 0.29$ & $0.75 \pm 0.32$ \\
\hline Girls & $0.51 \pm 0.29$ & $0.7 \pm 0.33$ & $0.76 \pm 0.46$ \\
\hline$p$ value & 0.78 & 0.37 & 0.94 \\
\hline
\end{tabular}

Table 3 Relation of serum $\mathrm{Cu}$ concentration by gender

\begin{tabular}{cccc}
\hline & \multicolumn{3}{c}{ Cu level $(\mathrm{mg} / \mathrm{L})$} \\
\hline FC group & Non-FC group & Healthy group \\
Mean \pm SD & Mean \pm SD & Mean \pm SD \\
\hline Boys & $1.18 \pm 0.37$ & $1.24 \pm 0.62$ & $0.76 \pm 0.36$ \\
\hline Girls & $1.11 \pm 0.26$ & $1.56 \pm 0.4$ & $0.48 \pm 0.16$ \\
\hline $\boldsymbol{p}$ value & 0.58 & 0.06 & 0.16 \\
\hline
\end{tabular}


Table 4 Comparing of serum $\mathrm{Zn}$ concentration in 3 study groups

\begin{tabular}{cccc}
\hline & $\begin{array}{c}\text { FC group } \\
\text { Mean } \pm \text { SD }\end{array}$ & $\begin{array}{c}\text { Non-FC group } \\
\text { Mean } \pm \text { SD }\end{array}$ & $\begin{array}{c}\text { Healthy group } \\
\text { Mean } \pm \text { SD }\end{array}$ \\
\hline $\begin{array}{c}\text { Zn level } \\
(\mathbf{m g} / \mathbf{l})\end{array}$ & $0.43 \pm 0.38$ & $0.66 \pm 0.37$ & $0.97 \pm 0.15$ \\
\hline $\boldsymbol{p}$ value & $0.008(1$ and 2 groups $)$ \\
\cline { 2 - 4 } & \multicolumn{2}{c}{0.002 (2 and 3 groups) } \\
\cline { 2 - 4 } & 0.001 (1 and 3 groups) \\
\hline
\end{tabular}

Table 5 Comparing of serum $\mathrm{Cu}$ concentration in 3 study groups

\begin{tabular}{|c|c|c|c|}
\hline & $\begin{array}{c}\text { FC group } \\
\text { Mean } \pm \text { SD }\end{array}$ & $\begin{array}{c}\text { Non-FC group } \\
\text { Mean } \pm \text { SD }\end{array}$ & $\begin{array}{c}\text { Healthy group } \\
\text { Mean } \pm \text { SD }\end{array}$ \\
\hline $\begin{array}{c}\text { Cu level } \\
(\mathrm{mg} / \mathrm{l})\end{array}$ & $1.16 \pm 0.38$ & $1.53 \pm 0.76$ & $0.53 \pm 0.24$ \\
\hline \multirow[t]{3}{*}{$p$ value } & \multicolumn{2}{|c|}{0.005 ( 1 and 2 groups) } & \\
\hline & & \multicolumn{2}{|c|}{0.001 (2 and 3 groups) } \\
\hline & & (1 and 3 groups & \\
\hline
\end{tabular}

convulsion and healthy children, without fever and convulsion). There was a statistically significant difference in mean serum zinc level in between febrile children without convulsion and healthy group patients. Mean serum $\mathrm{Cu}$ levels in children with FC and non-FC patients were significantly higher than healthy children. There were no statistically meaningful differences in the mean serum $\mathrm{Zn}$ and $\mathrm{Cu}$ levels in boys and girls.

Y1lmaz and Balc1 (11); Talebian et al. (12) Ganesh et al. (13), Amiri et al. (14) reported no significant difference in serum $\mathrm{Z}$ level in relation to sex, this is in agreement with result of our study.

Gheini et al. (15) Vidyasagar et al. (16) and Burhangnoglu et al.; (17) found the lower mean serum $\mathrm{Zn}$ level in children with febrile seizure than the other children without fever. Also, Mahyar et al. (18), Saghazadeh (19) and Amiri et al. (14) reported the lower serum $\mathrm{Zn}$ level in children with febrile seizure compared to control group. There was a correlation between serum $\mathrm{Zn}$ level and febrile seizure in Margaretha et al.; study (20). They reported that lower serum $\mathrm{Zn}$ level related to longer the duration of seizure. Results of our study was similar to Modarresi et al. (21) and Ehsanipour et al. (22) studies who found that serum $\mathrm{Zn}$ level was lower in children with febrile seizure than the other two control groups (febrile with non-convulsion and healthy children).

Children with febrile seizure in our study had meaningful higher serum $\mathrm{Cu}$ level than control group cases. This is in agreement with Prasad et al. (23) that found serum $\mathrm{Cu}$ levels in children with seizures were significantly increased and opposed to Amiri et al. (14) Yllmaz and Balc1; (11) who reported no significant change in serum $\mathrm{Cu}$ level in cases of febrile convulsion or Gheini et al. 
(15) who found mean serum $\mathrm{Cu}$ level in the control group was significantly lower than that of the case group.

\section{Conclusion}

We observed significant lower serum Zn level in children with febrile seizure and meaningful higher serum $\mathrm{Cu}$ level than control group cases. There was no significant difference in level of serum $\mathrm{Zn}$ and $\mathrm{Cu}$ in term of sex.

\section{Acknowledgement}

This work is the outcome of Pharm. D. thesis for Mehdi Mashhadiakbar with registration No 243 and was supported by a grant from the Research and Technology Deputy Vice-Chancellery of Mazandaran University of Medical Sciences.

\section{Conflict of interest}

The authors declare that they have no competing interests.

\section{References}

1. American Academy of Pediatrics. Clinical Practice Guideline Febrile Seizures: Guideline for the Neurodiagnostic Evaluation of the Child with a Simple Febrile Seizure. Pediatrics 2011; 127: 389-94.

2. Menkes J, Sarnat H. Paroxysmal disorders. In: Menkes J, Sankar R. Child Neurology. $6^{\text {th }}$ edition. Philadelphia, USA: Lippincott Williams \& Wilkins, A wolters Kluwer Company 2000; 987-90.

3. Tütüncüoğlu S, Kütükçüler N, Kepe L, Coker C, Berdeli A, Tekgül H. Proinflammatory cytokines, prostaglandins and zinc in febrile convulsions. Pediatr Int 2001; 43:235-39.

4. Pisacane A, Sansone R, Impagliazzo N, Coppola A, Rolando P, D'Apuzzo A, Tregrossi, C. Iron deficiency anaemia and febrile convulsions: case-control study in children under 2 years. BMJ 1996; 313, 343.

5. Prakash O, Deepak M, Ram SU. Cerebrospinal fluid zinc, magnesium, copper and gammaamino butyric acid levels in febrile seizures. $\mathbf{J}$ Pediatr Neurol 2007; 5: 39-44.
6. Anonymus, Minerals and trace elements. Available at: http://mefanetmotol.cuni.cz/articles.php?aid motol.cuni.cz/articles.php?aid=610. 14 Sep, 2009.

7. Tuula E. The adverse effects of Zinc deficiency. J Orthomolecular Med 1995; 10:146-64.

8. Izumi $\mathrm{Y}$, Ishii $\mathrm{K}$, Akiba $\mathrm{K}$, Hayashi $\mathrm{T}$. Hypozincemia during fever may trigger febrile convulsion. Med Hypotheses 1990; 32:77-80.

9. Dinarello CA. Infection, fever, and exogenous and endogenous pyrogens: some concepts have changed. J Endotoxin Res 2004; 10:201-22.

10. Gatti S, Vezzani A, Bartfai T. Mechanisms of fever and febrile seizures: putative role of the interleukin-1 system. Academic Press 2002; 169-88.

11. Yilmaz D, Balci O. Serum selenium and copper levels in children with simple febrile seizure and viral infections. Pediatr Practice Res 2014; 2:415.

12. Talebian A, Vakili Z. Talar SA, Kazerni M. Mousavi GA. Assessment of the relation between serum zinc and magnesium levels in children with febrile convulsion. Iran J Pathol 2009; 4:157-60.

13. Ganesh R, Janakiraman L. Serum Zinc levels in children with simple febrile seizure. Clin Pediatr (Phila) 2008; 47:164-6.

14. Amiri M, Farzin L, Moassesi ME, Sajadi F. Serum Trace Element Levels in Febrile Convulsion. Biol Tr Elems 2010; 135: 38-44.

15. Gheini S, Kiani A, Sedighei M, Hojabri K. Assessment of serum zinc, selenium and copper in simple febrile convulsions in children aged 6 to 60 months in Mohammad Kermanshahi Hospital in 2012. J Kermanshah Univ Med Sci 2015;19:16-23 (Persian).

16. Vidyasagar V, Venugopal BL, Darshan MS Comparison of serum zinc level in patients with simple febrile seizure versus acute febrile illness. Sch J App Med Sci 2015; 3:2210-19. 
17. Burhanoglu M, Tutuncuglu S, Coker C, Tekgül H, Ozgür T. Hypozincaemia in febrile convulsion. Eur J Pediatr 1996; 155:498-501.

18. Mahyar A, Pahlavan A, Varasteh-Nijad A. Serum zinc level in children with febrile seizure. Acta Medica Iranica 2008; 46:477-80.

19. Saghazadeh A, Mahmoudi M, Meysamie A, Gharedaghi M, Zamponi GW, Rezaei N. Possible role of trace elements in epilepsy and febrile seizures: a meta-analysis. Nutr Rev 2015;73:760-79.

20. Gattoo I, Harish R, Quyoom Hussain S. correlation of serum zinc level with simple febrile seizures: A Hospital based Prospective Case Control Study. Int J Pediatr 2015;3:509-15.
21. Rabbani MW, Ali I, Latif HZ, Basit A, Rabbani MA. Serum zinc level in children presenting with febrile seizures. Pak J Med Sci 2013; 29:1008-11.

22. Ehsanipour F, Talebi-Taher M, Harandi NV, Kani K. Serum zinc level with febrile convulsion and its comparison with that of control group. Iran J Pediatr 2009; 19: 65-8.

23. Prasad R, Singh A, Das B, Upadhyay R, Singh T, Mishra O. Cerebrospinal fluid and serum zinc, copper, magnesium and calcium levels in children with Idiopathic seizure. J Clin Diagn Res 2009; 3:1841-6. 